\title{
Some aspects of the competitiveness of Turkish regions and their tourism industry the example of Ardahan
}

\author{
Ahmet Bariscil * \\ Szent István University, Godoll’o, Hungary
}

\author{
Keywords \\ Competitiveness \\ Turkish regions \\ Tourism Industry
}

Received: 10 October 2017

Accepted: 18 October 2017

Published: 4 December 2017

\begin{abstract}
Competitiveness and its study is a global issue. Competitiveness can be therefore analyzed at the level of the world economy, but can be also described on a smaller scale, for instance on the lower parts of the global hierarchy, meaning the nation. So, as far as our topic is concerned, we can deal with role played by Turkey in the globalized market economy or the situation of given actors of a given sector of the Turkish national economy. In our present paper, we would like to concentrate on the interaction of space and economy. We are convinced that we can speak of the competitiveness of geographical units, such as regions and provinces, as well as of the competitiveness of the economic sector most utilizing them, the tourism industry. So, our goal is to show how interrelated these two phenomena are the competitiveness of regions and the competitiveness of the tourism industry, one of the key sectors of the Turkish national economy.
\end{abstract}

(C) 2017 The Author(s). Published by TAF Publishing.

\section{INTRODUCTION}

Competitiveness-as we would define it later-is an ability of competing or doing better than other actors of economy. Competitiveness depends on two major sets of conditions. The first one of those sets can be described as the inner policy of the enterprises, organizations, institutions or nations. As these actors develop a complete frame of infrastructures both knowledge related and physical, the very basis of all competitiveness is the environment the actor creates for itself. Enterprises, organizations, institutions or nations built on solid knowledge and physical infrastructures, indeed, have an advantage on the others. Infrastructure though is by far not enough to be fully successful on the market, it should be accompanied by some essential outer conditions. Among those outer conditions, we can stress the importance of the work force supply, itself influencing the above mentioned knowledge related infrastructure. Other outer conditions include the prices of products and services necessary for the enterprises and institutions or the productivity and performance of the partners.

Competitiveness and its study is a global issue. Competitiveness can be therefore analyzed on the level of the world economy, but can be also described on a smaller scale, for instance on the lower parts of the global hierarchy, meaning the nation. So, as far as our topic is concerned, we can deal with role played by Turkey in the globalized market economy or the situation of given actors of a given sector of the Turkish national economy.

In our present paper, we would like to concentrate on the interaction of space and economy. We are convinced that we can speak of the competitiveness of geographical

\footnotetext{
${ }^{*}$ Corresponding author: Ahmet Bariscil

${ }^{\dagger}$ Email: ahmetb121@gmail.com
} 
units, such as regions and provinces, as well as of the competitiveness of the economic sector most utilizing them, the tourism industry. So, our goal is to show how interrelated are these two phenomena, the competitiveness of regions and the competitiveness of the tourism industry, one of the key sectors of the Turkish national economy.

\section{LITERATURE AND METHODOLOGY}

We would like to base our argumentation on two types of sources. First, we would make use of the general economic and scientific knowledge to discuss what competition and competitiveness are, and how they can be defined in general and in the framework of the Turkish Republic in particular. Second, we would like to use as authentic documents reports produced by the main Turkish think tanks dealing with the issue of competition and competitiveness in Turkey. Here we can count on three major centers: the official Competitiveness Institute (Rekabet Kurumu), the most important center formed by independent researchers named URAK and the universities. In the introductory chapters we might use sources in English, but the majority of the reports are in Turkish language.

Our methodology is an interdisciplinary one in the sense that our topic is an intersection of the sciences of geography and economy as space, regions and provinces are all key technical terms in both. Besides being profoundly interdisciplinary, we would like to keep our analysis both qualitative and quantitative, qualitative because our aim is to describe a certain development and its possible sustainability, quantitative because we will have a special concern: the numbers showing the reality of competitiveness and sustainable development in the Turkish tourism industry.

\section{Definition of Competitiveness}

To provide a more understandable definition to the notion of competitiveness, one has to ponder over the very meaning of competition as competitiveness is only possible where there is competition. We can speak of competition in economy when there are at least two firms being interested in the exactly same field. Theoretically we can imagine a perfect competitive market where the firms have the exactly same size, they produce the exactly same quality and quantity of products or services using a similar infrastructure and commercialize for the exactly same price. This idealization of market economy rarely happens in reality as most firms differ in terms of size, infrastructure, quality and quantity of production etc. In this ideal case, the firms have no real influence on the market in general and the prices in particular as the consumers are perplexed by the similitude of their products and services.

Competition starts when at least small differences can be identified among the producers. In this situation products and services are almost identical, so as the buyers can substitute one with another; the prices offered by the firms are known; the market is free, so both the sellers and the buyers can have an open access to it; and finally the costs are low, so both sides can readily find other partners and change business strategies.

So, competition is given in economy when the products are neither completely interchangeable, nor fully different. This means that the fiercest competition is there if there are small differences in the market. If competition is so, then competitiveness is the capability of working with prosperity on a market where actors are resembling.

The very purpose of competition and competitiveness is to realize profit maximization. As the conditions of the firms on the market are very much alike, the enterprises have to take care of their output. This is why for being competitive a perfect planification is needed. For all products and services, there is a quantity which can be sold for a minimum, a maximum and an average price. The task of the management is to calculate the 
quantity where a highest profit is feasible. This business strategy can be termed profit maximizing behavior.

The very purpose of competition and competitiveness is to realize profit maximization. As the conditions of the firms on the market are very much alike, the enterprises have to take care of their output. This is why for being competitive a perfect planification is needed. For all products and services, there is a quantity which can be sold for a minimum, a maximum and an average price. The task of the management is to calculate the quantity where a highest profit is feasible. This business strategy can be termed profit maximizing behavior.

Different firms calculate the ideal prices both input and output- in different ways, and this might be the reason behind the gains and benefits of a certain actor. At the beginning, we could observe a certain equilibrium on the market, later this initial symmetry is overthrown by one of the actors; this can be called a first shock on the market. This shock provokes a change in the demand and after a while the equilibrium can be attained for a second time. Firms are interested in raising the market price of their own output, but by doing so they partly ruin the market's equilibrium. This ability of competitive firms is the market power.

Market power is the capability of an enterprise to realize the highest possible income on a not perfectly competitive market. The market poor can be partial or total. We can speak of total market power in the cases when an actor of market has subjugated the market itself and defines the prices for the input and the output, and controls all the aspects of the market. A less dominant position can be gained by those firms which take under control a part of the market: the input, the output or the consumers.

Of course, the logic of capitalism is profit and market domination. So, this is why the competitive companies try to have the highest possible market power. This is a world wide phenomenon that can be analyzed in any country, including Turkey.

The Concept of Competitiveness as it is Understood in Turkey

There are a number of ways of explaining the economic phenomenon of competition and competitiveness and not surprisingly their definitions might differ from country to country. Though the very phenomenon is linked to the general process of globalization, it does not exclude the fact that even competition and competitiveness are approached in diverse manners across the globe. In Turkey, experts underline that competition and competitiveness are not simply increasing profit of a company, the widening of the opportunities of a region or the deepening of the well being of a nation, but also their comparison with similar actors in other countries as competitiveness can be understood on a global level. According to the Turkish scholars the definition of competitiveness accepted by the majority today also includes the ability to optimize the cost of resources used in production as well as the ability of delivering the products and services on time and to the desired place (Filiztekin and Carat, 2010).

The Turkish authors draw our attention to two important features of competition and competitiveness. One of them is that real global competition is to be observed at the level of foreign trade, the second is that though Turks nowadays tend to do business abroad, they are not fully aware of what is going on in the other countries (Filiztekin and Carat, 2010). So, for Turks it is a major challenge to get liable information, possibly in Turkish language as many Turkish traders do no do nor really speak foreign tongues including English. So, to be competitive also requires to be educated.

If the proper education is provided, one can see the real dichotomies of global economy and value the real strength of a national economy. Turkish experts are of the opinion that 
the first effect of globalization is manifesting itself in the emergence of competitive pressures in almost every area of the economy. It is expected that the competition of goods will lift the price differences between countries (Ovali, 2014; Selvina, 2016). Turks, in fact, think that there are three traditional and a new type of competitive pressure. The main pressure comes from the West as the focus of Turkish economy is the West and the member states of the European Union (EU) are the most important trade partners of the country. At the same time, there is another pressure coming from the side of the fellow Muslim countries of the Middle East and the Turkic nations of Central Asia. The new focus of Turkey and the new source of global pressure is composed of the emerging markets of Russia and China.

Though there were in the recent months and years a number of misunderstanding between the Turkish Republic and the European Union, we still believe that Europe remains the focus and the source of competitive pressure. During the last twenty years, Turkey has adopted various free market policies and other structural economic reforms, such as the liberalization of controls on trade and investment, the abolition of regulations and privatization. Such measures include the signing of a Customs Union Agreement with the European Union and the harmonization of its policies and institutions with this economic and political integration. The amount of Foreign Direct Investment (FDI) that Turkey has recently attracted has significantly underperformed the peer and competing countries, while the mutual trade with the EU has been remarkably above 50\% (Tepav, 2007). The above fact shows that competition with similar countries and success in the mutual trade with the EU are not totally interlinked. Turkey might underperform the other emerging economies, but still find the way to do business with Europe.

The competitiveness of Turkey depends on various factors and on ever evolving relationships with a number of regions of the World, mainly the European Union, the Middle East, Central Asia, Russia and China. This interdependence can also be expressed with numbers. There must be therefore an option to produce an index to show the competitiveness of Turkey. Globally and in Turkey too arises the question of what should be added to such a statistics, should it be purely economic or it might also take into account the social and environmental factors. While the debate about the influence of institutions and well governed countries on the competitiveness has gained importance recently, international indices that measure competition power have started to use environmental and social indicators as a component of long-term sustainable growth (Dilek and $\mathrm{Al}, 2016$ ). The methodology used by the European agency of Eurostat and recently adopted by the Turks is focusing on the regional differences. The inclusion of human factors into the measurement of competitiveness clearly show the advantages and the disadvantages of given regions. While the sub-indices of the competition index show that the difference between the provinces in finance, market size and infrastructures continues to open up, macroeconomic stability and the index of cities such as human capital are getting closer to each other's competition index (Dilek and Al, 2016; Wasike, 2017).

The notion of competition and competitiveness in Turkey are connected to the process of globalization and the importance of foreign trade. It is used to describe the differences between countries or provinces within Turkey.

Short History of the Study of Competition and Competitiveness in Turkey Though the first researches on competition and competitiveness started earlier, it was in the 1990's that this field could attract the interest of both the public and the private sectors.

The Turkish constitution drafted in 1982 after a military coup and still in vigor rec- 
ognizes the right of free investment and obliges the government to safeguard the frame of market economy. In 1994, the Law on the Protection of Competition (Law No. 4054) was adopted, and in 1997 the Competition Authority (Rekabet, 2013), which is the authority responsible for implementing this Law, was established. As a result of the detailed examination and investigation processes, it punishes enterprises that distort, obstruct or restrict competition in the market; it supervises the ongoing privatization process; prevents monopolization in sectors where it might hurt the efficiency of Turkish economy; it ensures that competition conditions are dominant in the market by sending opinions to relevant public institutions and organizations regarding the various laws and regulations that affect or restrict the competition (Rekabet, 2013).

The social-self organization and the establishment of the National Competition Research Institute (Urak, 2014) was initiated by Michael Porter from the American Harvard University who has created a very broad platform with the involvement of various government agencies, universities and NGOs in 1999. This platform was then called Competitive Advantage of Turkey (CAT). Within the scope of CAT, the sectors with competitive advantage of Turkey were identified with Porter's methodology and the first candidates selected from these sectors were assigned to a professional training. This institution adopted its present name in 2004 (Urak, 2014).

After the public and the private sectors, universities started also to contribute to the research of competition and competitiveness in Turkey. One of those higher education institutions involved in this sector is the Ankara based Beyazit Yildirim University. Its center does not only do research on the field but provides actors of the market with competition related services. Cluster Academy and Competition Research Center (Rekmer, n.d) is a project and consultancy center that provides services in the fields of competition, innovation, entrepreneurship, cluster and strategy. By bringing together the business world and academia and finding solutions to the problems encountered, Rekmer, which has developed innovative projects, contributes to the achievement of the visionary goals of both the university concerned and the firms (Rekmer, n.d).

\section{Regional Competitiveness}

Until this point, our main focus was the presentation of the general meaning of competition and competitiveness and its understanding in Turkey. We think that before continuing with the deeper part of our analysis, we should quickly define how competitiveness is perceived as far as regions and provinces are concerned.

According to Martin (2003), there are two main forms of regional competitiveness. There is a microeconomic level composed of an aggregate of firm competitiveness of companies in a region that are able to consistently and profitably produce products that meet the requirements of an open market in terms of price and quality; and there is a macroeconomic level where mobile factors such as the migration of capitals and work forces are to be taken into consideration (Martin, 2003) Migration here does not mean a simple movement from one point to another, but the mobility of a part of the global capital and production units and their reorganization in the given space (city, province, region) thanks to the developing technological infrastructure (Albayrak and Erkut, 2010). In the effort to attract capital, cities, provinces and regions with high accessibility benefit from low labor force fees and low bureaucratic obstacles in legal and administrative terms, due to the integrated communication and transportation channels with the international economy. These are, in 
Some Aspects of the Competitiveness of Turkish Regions and Provinces

The Turkish Republic is composed of 7 regions and within them 81 provinces. The 7 regions are as follows: the Mediterranean and the Aegean regions in the South, Southeastern and Eastern Anatolia in the East, the Black Sea region in the North, the Marmara Sea region in the West and Central Anatolia with the nations capital Ankara in the center of the country.

Turkish experts deal with both administrative levels. We can easily find analyses concerning the larger units, region (known in Turkish as bölge) and and smaller provinces (known in Turkish as il). Having said so, we would first overview the level of the bölges and later present the question of the ils.

Turkey always has been a country characterized by great regional discrepancies since the early Ottoman times until today. During the first era of the Turkish Republic which lasted from 1923 its declaration until 1946, the introduction of a democratic multi-party system, the Turkish leadership did not confront the issue of regional differences. After the rise to power of the Democrats in 1950 and the military coup deposing them in 1960, politicians and policy makers started to tackle the question of economic divergence of the Turkish regions. Two main political strategies can be seen since the 1960's, -some of them still in vigor-, on one hand developed regions are dotted with further development plans focusing on their respective potentials, whereas underdeveloped regions benefit from a certain number of privileges like lower taxes or governmental help for those who want to invest there. Since 1963, the Turkish government has also implemented a series of five year development plans for selected regions. The first few of them were the Eastern Marmara subregion in Western Turkey, the Cukurova subregion in Southern Turkey, the coal rich subregion of Zonguldak and the tourism themed subregion of Antalya on the Mediterranean. These pilot regions already having some potentials were used as a sample between 1963 and 1967 for proposing further development plans (Albayrak and Erkut, 2010).

The above example shows that the concept of regional development in order to make disappear the heterogeneity of the Turkish economy exists for more than 50 years. The idea of competitiveness was added to it in 2004. In 2006, a national project called Competitiveness/Clustering/Internal development-Local dynamics started to be applied for a number of new pilot regions and subregions. The list includes again the area around Zonguldak, a once prosperous mining region trying to find again an economic equilibrium after the privatization of the coal industry. The three other subregions selected by the government of Justice and Development Party are the Basin of the Yesilirmak river, the Eastern Black sea subregion and the most underdeveloped area of Eastern Anatolia (Albayrak and Erkut, 2010). If we compare the strategy of the 1960's with the strategy of the 2000's, we can see an important shift. Fifty years ago, the policy makers opted for development plans in already more or less developed places where there was already a certain economic potential, whereas nowadays with the use of the concept of competitiveness, less fortunate regions can also benefit from this type of central planification. Naturally less competitive regions are now considered priority areas by the government.

There are two important outer factors in the above change in approaching regional development. First, Turkey and the Turkish experts now benefit from all the scientific advancement made in the field of competitiveness. Second, the country has become a candidate for the European Union. Though there are significant political debates between Turkey and the EU, the adhesion process is still going on and is still favored by a number of European programs, like regional aid projects, forcing Turkey to adopt the European way of thinking. The Turkish government had to realize the importance of regional com- 
petitiveness in 1999 when at the Helsinki summit, they were told so by the instances of the EU (Vatansever Deviren and Yildiz, 2014). In Turkey, attempts were made to establish a central development agency in the 1990's, but it started its activities only in 2006 (Vatansever Deviren and Yildiz, 2014). Supported by pre-accession funds for the 2007-2013 period 15 regional development centers were opened under the coordination of the Turkish Ministry of Industry and Trade in the regions and subregions where the per capita income is lower than the $75 \%$ of the national average (Albayrak and Erkut, 2010). Among the primary objectives of these development agencies both in the world and in Turkey is to provide a competitive structure for the regions they are in. After 2006, the governance of regional politics strengthened; particularly with the establishment of development agencies, regional level analyses, strategy development and project implementation activities have increased in number.

It can be argued that Turkey is heading towards a new understanding of regional development agencies, central planning authorities, local governments and the private sector that start to work together and increase regional competitiveness (Eryllmaz and Tuncer, 2013). Regional development agencies in Turkey are confronted as one of the most important structures in the local scale today, where increasing competitive power has a critical mass.

To see what the regional competitiveness is in reality in the framework of Turkey we have to compare the less and the most competitive regions: respectively Eastern Anatolia and the Marmara Sea regions. The regional imbalance is one of the most important agenda items in Turkey in the development process. In the evaluations made on the basis of economic indicators, there has been a decline in the whole of Eastern Anatolia since the foundation of the republic. If necessary measures are not taken, the migration from the Eastern Anatolia region to the west of Turkey will continue. As the majority of the policy makers are from the Western part of the country, they make subways and overpass almost everyday there, they would not be able to solve the traffic problem in the East. In order to make people happy, especially in the region where they are born, essential necessities must be met. Economic measures here are not only important from the economic point of view but also from the angle of social balance as Eastern Anatolia is very fragile multiethnic region known to Turks as the Lock of Anatolia: the one who possess it, rules over the rest of Turkey, too.

Using an index adapted to the Turkish reality by Turkish economists the five less competitive provinces or ils are all located in the Eastern Anatolia region, whereas the five most competitive ones in the Western part of the country. In 2007, the less competitive province was the Eastern Anatolian province of Ardahan bordering Georgia with 3,5, Istanbul the country's economic hub has an index almost 30 times higher: 90,06 (Alkin, Bulu and Kaya, 2007). According to 2007-2008 and 2008-2009 results, Ardahan ranked 79th in the Competitiveness Index among the Provinces and rose to 78th place according to 2009-2010 General Index value. According to the Branding Ability and Innovation Index of 2007-2008 and 2008-2009, Ardahan ranks 81st (the last among the provinces) and rose to 78th rank according to 2009-2010 data (Tutar et al., 2013). So, a very slight improvement could be observed, but still Ardahan very simply cannot survive without the urgent help of the central government. The need for state investments and incentives in the province of Ardahan, is quite high. Ardahan is devastated by the mobile factors detailed in the previous chapter. The rare highly trained local work force quits the country, whereas the foreign investors do not want to enter it. The current employment problem and the inability to attract private sector investments cause low competitiveness through- 
out the province of Ardahan (Topcuoglu, Oral and Demir, 2016). Ardahan is a traditional farmland. Some specialists therefore say that by providing the local people with the necessary training and seminars to ensure a transition to a more modern structure in livestock, we can create an effect that increases the added value of agriculture. The Ardahan province has a considerable potential for agricultural production, especially for organic production, but the continued use of traditional methods of production in the region reduces the yield (Abaci, 2015). As one of our current topics is tourism, we should not forget that the development of the natural beauty, historical structure and winter tourism areas that the province has, and making promotions to arrange that local and foreign tourists arrive, will contribute to the creation of new investments and an increase in quality employment (Topcuoglu et al., 2016).

As we have said it earlier in this chapter, Istanbul leads by far the competitiveness index list of Turkey. The industries and services of the former imperial city that lies on the two shores of the Strait of the Bosphor are not only competitive on the Turkish level, but also on the international level. It has to be noted that for a real global competitiveness, Istanbul still needs the help of Ankara, the central government. According to the head of the Industrial Chamber of Istanbul (ISO), $27 \%$ of the Turkish industrial production comes from the city and $46,1 \%$ of the Turkish tax income of the state comes also from Istanbul (Hurriyet, 2015). These numbers clearly show that although Istanbul is still said to be an industrial city, it is home to an ever growing scene of services, naturally many times related to our other topic, the tourism industry. This level that Istanbul alone has, makes it a leading competitive region (Albayrak and Erkut, 2011).

\section{Some Aspects of the Competitiveness of the Turkish Tourism Industry}

It is clear that the relative geographical location, the fact of being close or far from the centers, influences the chances of a region as well as its competitiveness. In certain sectors, the localization factor is energy, as it is the case with the aluminum industry consuming a tremendous amount of energy, in others it is the row material as certain ingredients like the sugar beet for the sugar production- cannot be transported on a long distance. To urism differs from any of the traditional industries as it can develop around anything from natural beauty to cultural heritage, from hot water springs to traditions or sporting facilities. So, theoretically, one can speak of the improvement of the tourism industry regardless of the general competitiveness of a region. Again theoretically the tourism business of Ardahan can become one day as competitive as that of Istanbul.

When we look at Turkey, it is seen that the tourism sector, especially after 1980, has shown great progress and has taken the role of locomotive in the development of the country. In recent years, the Turkish economy was rebuilt to support an export-oriented industrialization, which is accepted as the basic principle of free market economy in Turkey, meanwhile the tourism sector has been seen as an easy, effective, efficient and relatively cheap tool (Bahar, 2006). Turkey is an important destination among vacationers, but due to the instability in the Middle East, nowadays it gets a smaller share than what we can think compared to its potentials. The World Economic Forum ranks Turkey 44th in 2015 with a competitiveness index of 4,08, slightly behind Hungary with 4,14 (World Economic Forum, 2015).

It is important to underline that in tourism destinations compete and not countries. Most travelers do not choose among nations, but among places proposing almost identical themes. For example, Istanbul, as a culture, business and congress tourism centre may be in competition with its 2 European counterparts; central Anatolia, as a culture tourism centre, with mainland Greece region and eastern European countries. In this sense, for 
summer vacation tourism Spain is not expected to be in direct competition with Turkey, but the Balearic Islands may be with the Aegean and Mediterranean coasts of Turkey (Kozak, 1999). One can wonder what the factors influencing the choices of an individual traveler or a person buying a package tour are. We first might think that the price determines the option, but when it comes to going abroad, we are ready to pay more if we are advised to do so by fellow passengers. Intensifying competition through growing number of holiday destinations, offering similar products and services, and increase in consumer quality awareness mean that the concept of tourist satisfaction is a vital ingredient in the recipe for success (Yüksel and Yüksel, 2000). So, destinations do not always compete in terms of offer, but in the manners they receive holiday makers.

The transfer in the consumption habits of travelers from cheap destination to quality destinations force destinations themselves to change in order to remain or become not only popular with backpackers, but also competitive on the global scale. While authorities involved in the tourism industry, have started to recognize the importance of quality improvement in a strategy for making Turkish tourism more competitive, these objectives seem to have been implemented in piecemeal fashion and yet to be materialized completely (Yüksel and Yüksel, 2000). The hospitality industry, in fact, is a very complicated supply chain where the elements are highly interdependent. A travel is often composed of a flight, a hotel, restaurants, museum and other places of interest, diverse attractions from theme parks to sea side etc. It is enough if one of them dissatisfies the holiday maker to make the summer experience in Turkey horrible. So, it is not enough if an actor in the supply chain performs perfectly, it has to be in touch with similar quality service provider to ensure a maximal consumer satisfaction and in this way to raise the competitiveness of the destination.

A Turkish case study clearly indicates that the quality of the services aimed at the tourists is not the only factor of satisfaction and competitiveness. The competitiveness minded tourism development plan of Seferihisar, a heavily touristed district in the Aegean province of Izmir shows that there is a direct connection between the factors of destination competitiveness and quality of life issues (Küçükaltan and Pirnar, 2016) It is proved that a number of good decisions taken by the municipality of Seferihisar could contribute both to the satisfaction of the holiday makers and the competitiveness of the place. A group of 300 local volunteers was entrusted to come up with new ideas. The inclusion of residents is a novelty and a source of good in this longtime centrally governed country. For the sake of the project, Seferihisar went green in the sense that to attract more ecologically minded travelers, they started to use renewable sources of energy. Now, alternative energy runs the local tram network, the solar energy the bicycle service station and even a biogas station have been opened. These inventions and innovations are rare in Turkey but more and more common in the West. After making sure that the eco-friendly travelers would come to Seferihisar, the local authorities started to rebuild the cultural heritage sites of the area including the antic city of Teos, the Ottoman remnants of the Quranic school of the Duzce Madrassah and two historical Turkish bathes as well as the impressive Sigacik Castle. Though the main tourist attraction here is the warm sea and the sandy beaches, people of Seferihisar are proud of their centuries long history and are willing to expose in a modern way. People in Seferihisar have realized that foreign visitors to their locality are interested in buying healthy food items Therefore they have established a special market serving biologically grown fruits and vegetables. This market was not the only place where locals and visitors could socialize. On the proposal of locals, the municipality designated the Sigacik Green Area and the Ataturk Street to be a meeting point to chat with 
the incoming foreigners. Again as an idea taken from the West, bicycle paths started to connect various parts of the town center (Küçükaltan and Pirnar, 2016). These ideas and many similar one could rejuvenate the image and the style of the district of Seferihisar and raise its competitiveness as a modern tourist destination. Seferihisar can serve as an example for other Turkish destinations such as Ardahan or even Istanbul.

We have presented the landlocked province of Ardahan as one of the poorest and less competitive places in Turkey. We think that tourism might be a key element in promoting and making Ardahan much more competitive. There are already a number of projects going on in the province, but they are not yet coordinated and a concise plan is needed taking into account the natural, cultural and human capacities of the province.

Ardahan is a mountainous area. Exception made for the district of Posof, all points of the province are at least 1900 meters above sea level. It has a very tough dry continental climate with a very limited quantity of rain during its long and sunny summer, but relatively high quantity of snow during the equally harsh winters when the temperatures can be as low as -35 centigrade. The presence of the snow makes Ardahan a good alternative to the more centrally located and better known ski centers of Turkey in the city of Erzurum. The very problem is that the natural opportunity is there, but Ardahan lacks the complete infrastructure needed to become a winter sport heaven. For this reason, the Ardahan Provincial Winter Sports and Highland Tourism Center Executive Committee was established in 1998. This commission started to work at the location of Ugurludag in the village of Solizcam, which is $15 \mathrm{~km}$ away from the province center, and started to work on the construction of a facility that will change the face of Ardahan province from both economical and tourism point of view (Apali, 2008). The Program of Competitive Sectors (RSP) aimed at raising the competitiveness of Eastern Anatolia now finances the installation of a chair lift in Solizcam (Altun, 2007).

Because of the climate of Ardahan and the fact that settlements are not widespread, many natural beauties have been preserved. Among them is the Cildir Lake, the second largest lake in the Eastern Anatolian region. The trout and the yellow-headed carp that live in this lake and in the surrounding other ones, are rare and appreciated fish. Cildir Lake's hosting of many activities as a result of winter frosts shows its touristic potential. It is a local tradition and it is also increasingly popular with the rare visitors to ride a horse on the frozen lake. Since 2013 an important local equestrian festival is held on the ice. (Çimen, 2013) Malakan horse (Ardahan horse) is recognized as one of the local race horses of Anatolia (Apali, 2008).

In addition to the historical and geographical assets, like the Ardahan Castle featuring remnants from the prehistoric ages to the time of the Ottoman Empire, that make up Ardahan's tourism potential, there are also cultural and sporting opportunities. It is possible for people who want to get away from dense urban centers to enjoy the possibility of sustainable tourism, nature tourism, eco tourism, green tourism or rural tourism in Ardahan unspoiled and well off the beaten tracks (Çimen, 2013). Lovers of sustainable tourism can do different activities in Ardahan. One of them is the power hiking and trekking as Ardahan is both home to large easily accessible plateaus. For example the very green Yalnizcam Plateau is located at $15 \mathrm{~km}$ from the capital of the province. Those who wish to adventure into the highest mountains, can go trekking in the untouched mountains of Akbaba, Allahuekber, Kabak or Kisir. The Kura River, the longest river of the province is born in the Eastern Anatolian region of Turkey, merges with the Aras River in Azerbaijan and pours into the Caspian Sea. There is here a high potential for rafting and canoeing. Some experiments have been made, but still there is not a permanent infrastructure to get visi- 
tors (Apali, 2008).

In this short description of the potentials, we always mentioned that the area is full of possibilities, but it lacks proper infrastructure to improve the quality of the services, to ensure the satisfaction of the visitors and finally to raise the competitiveness of the tourism industry of the province. Now, let's see what is in the master plan elaborated by the local branch of the General Directorate of Nature Conservation and National Parks for the time period between 2013 and 2023. After enumerating the natural potential and before coming to the proposal, the experts of the General Directorate have a very valid point showing that the satisfaction of the visitors cannot be the only concern when dealing with the issue of destination competitiveness. Indeed, there is a local tolerance limit for tourism as tourism includes the adverse effects on the local people and we have to avoid the conflicts between the foreigners and the local people. This factor has a key role in tourism development. If local people do not support tourism, development will never happen (Zengin and Yilmaz, 2010) The most important proposition is to open up the province of Ardahan to the outside world by establishing one more crossing point to the neighboring Georgia in Aktas, as the one in Turkgozu is not enough. The number of the accommodation option is not satisfying either. There are only a few two stars hotel around, there is a proposition to build more and better hotels in Ardahan (Zengin and Yllmaz, 2010). The authors of the master plan realize that to become competitive, one has to build on features that work already. In Ardahan, the most appealing center to initiate the visitors to the geology, the flora and the fauna of the region is the Cemal Tural Fidanligi Tabiat Parki. This conservation area can be a very good basis for further developments if it is made known across Turkey and the World and is better accessible in winter (Zengin and Yllmaz, 2010). The promotion of this place can be understood as a pilot project to make Ardahan's tourism industry more competitive.

Ardahan would become one day a competitive tourist destination if all these potentials are used and future developments are organized in an innovative way as in the above detailed case of Seferihisar. Especially western visitors would come to Ardahan if they find there anything added to the ordinary attraction. This can be a bicycle path, a via ferrata, and an adventure park or a surprising panoramic view point. Unless the local residents and the local authorities think the same way as in Seferihisar, they would not be able to compete with other regions. To build a proper winter sport center in Yalnizcam is indeed a good idea, but it should be special, otherwise it would not attract big crowds. Competitiveness in tourism lies in special offers.

\section{CONCLUSION}

Today, the rapidly growing population worldwide and the decreasing natural resources are increasing the importance of adequate and balanced economic decisions in the protection and development of quality of life. Competitiveness in this evolving global environment is an ability of doing a business better than our almost identical counterparts.

We witness a general development in the world of tourism after the end of the 2008 economic crisis. We expect that leisure time and quality of life will be further increased in the future and that tourism will show rapid development and growth in the $21^{\text {st }}$ century. The most important point of this development and growth process in the tourism sector (with some changing points in terms of destinations, products, markets and tourists) is that the new century has entered new trends: customer satisfaction and competitive power. It is expected that in the sector where the destinations are becoming a brand, destinations that can provide customer satisfaction, good-quality service, competitive price, and competitive advantage. 
Competitiveness in regional development in general and tourism and destination management in particular depends on how one can make his or her region or tourist services special, different from the already existing schemes, special and at the same time innovative and inclusive. Innovative in the sense of using the state-of-the-art technologies and inclusive in the sense that all partners-locals and visitors alike- are consulted during the development process. Ardahan is at the beginning point of this process. Ardahan is still very far both in mind and body from its more competitive competitors. To become really competitive, Ardahan has to look around the world for finding anything extraordinary to propose to its visitors.

\section{REFERENCES}

Abaci, Zehra Tugba. 2015. Applicability of advanced technologies in Ardahan agriculture. Iğdır University Journal of the Institute of Science and Technology 5, no. 1: 37-44. D0I: 10.29133/yyutbd.235931

Albayrak, Ayşe Nur, and Gülden Erkut. 2010. Türkiye'de bölgesel rekabet gücü analizi. Megaron 5, no. 3: 137-148. Albayrak, Ayșe Nur, and Gülden Erkut. 2011. Türkiye'de il ve bölgelerin rekabet gücü analizi. Itüdergisi/A Mimarlık, Plan- Iama, Tasarım 9, no. 2: 155-165.

Alkin, Kerem, Melih Bulu, and Hüseyin Kaya. 2007. Iller arasi rekabet endeksi: Turkiye'deki illerin rekabetcilik seviyelerin goreceli olarak olculebilmesi icin bir Yaklasim. İstanbul Ticaret Üniversitesi Sosyal Bilimler Dergisi 6, no. 11: 221- 235. Altun, Murat. 2007. Rekabetçi Sektörler Programı (RSP), milli geliri Türkiye ortalamasının altında kalan şehirlerde turizm projelerine destek veriyor. URL: https://bit.ly/2ES2WY9 (accessed on August 18, 2012).

Apali, Y. 2008. Ekoturizmin sosyolojik açıdan değerlendirilmesi ve Ardahan'ın ekoturizm potansiyeli. Íktisadi ve İdari Bil- $\quad$ imler Fakültesi Dergisi 2, no. 8: 111-124.

Bahar, Ozan. 2006. Turizm sektörünün Türkiye'nin ekonomik büyümesi uzerindeki etkisi: VAR analizi Yaklaşımı. Yönetim ve Ekonomi: Celal Bayar Üniversitesi İktisadi ve İdari Bilimler Fakültesi Dergisi 13, no. 2: 137-150.

Çimen, Hürriyet. 2013. Ardahan'ın turizm potansiyeli. Dergi Karadeniz 21, no. 21: 307-315. D0I: 10.17498/kdeniz.279656 Dilek, P. Y., and Al N. 2016. Turkiye icin bir rekabet endeksi. Istanbul, Turkey: Edam.

Eryılmaz, Bilal, and Aziz Tuncer. 2013. Avrupa birliği uyum sürecinde bölgesel kalkınma politikaları: Bölgesel kalkınma ajansları ve Türkiye uygulaması. Akademik Incelemeler Dergisi 8, no. 1: 1-25.

Filiztekin, A., and Carat S. 2010. Türkiye'nin dış ticarette rekabet Gücü: Seçilmiş ulkeler, sektörler-mal grupları ve en- deksler bazında karşılaşstırmalı bir analiz. Istanbul, Turkey: Sektörel Dernekler Federasyonu.

Hurriyet. 2015. íSO başkanı bahçıvan: 'Rekabet gücü için destek lazım. URL: https://bit.ly/2HtSQln (accessed on August 3, 2016).

Kozak, Metin. 1999. Destination competitiveness measurement: Analysis of effective factors and indicators. Paper pre- $\quad$ sented at the $39^{\text {th }}$ Congress of the European Regional Science Association: Regional Cohesion and Competitiveness in $21^{\text {st }}$ Century Europe, Dublin, Irland.

Küçükaltan, Ebru Günlü, and Ige Pirnar. 2016. Competitiveness factors of a tourism destination and impact on residents' quality of life: The case of Cittaslow-Seferihisar. Journal of Tourism, Heritage \& Services Marketing 2, no. 1: 22-29. Martin, Ronald L. 2003. A study on the factors of regional competitiveness. A draft final report for the European com- mission directorate-general regional policy. URL: https://bit.ly/2lTGvMn (accessed on October 3, 2008).

Ovali, Serap. 2014. Küresel rekabet gücü açısından Türkiye'nin konumu üzerine bir değerlendirme. Uluslararası Íktisadi- $\quad$ ve İdari İncelemeler Dergisi 13, no. 13: 17-36. DoI: 10.18092/ijeas.58881

Rekabet, Kurumu. 2013. Hakkimizda. URL: https://bit.ly/2H8SKAf (accessed on April 3, 2008).

Rekmer, Nedir. n.d. Rekmer. URL: https://bit.ly/2J2y3Ta (accessed on February 3, 2018).

Selvina, M. 2016. Indonesian accountant vs foreign accountant in Indonesian job competition as an effect of Asean economic community 2015. International Journal of Business and Administrative Studies 2, 1: 16-19.

DOI: 10.20469 /ijbas.2.10004-1

Tepav. 2007. Türkiye'de rekabetçilik ve düzenleme. URL: https://bit.ly/2ESXJPq (accessed on February 7, 2016). ISSN: 2414-3111 
Topcuoglu, A., Oral, I.O., and Demir, M. 2016. Ardahan ilinin sosyo-ekonomik yapisinin gorunumu. Ardahan Üniversitesi Íktisadi ve Ídari Bilimler Fakültesi Dergisi 3, no. 3: 131-142.

Tutar, H., B. Aydoğdu, G. Elyıldırım, M. Dik, M. Sarışen, and O. G. İnce. 2013. Iğdır'ın sosyo-ekonomik durumu ve uygun yatırım alanları. TC Serhat Kalkınma Ajansı Iğdır Yatırım Destek Ofisi Yayını, Iğdır. Kars, Turkey: T. C. Serhat Devel- opment Agency (Serka).

Urak. 2014. Tarihcemiz. URL: https://bit.ly/2qE6Qi3 (accessed on January 21, 2018).

Vatansever Deviren, Nursen, and Onur Yildiz. 2014. Bölgesel rekabet gücünün arttirilmasinda bölgesel kalkinma ajanslar- inin rolü: Geka orneği. Journal of International Social Research 7, no. 35: 23-34.

Wasike, C. N. 2017. Financial regulation as moderating, influence of corporate governance, institutional quality, human cap- ital and firm size on financial institutions performance in Kenya. Journal of Administrative and Business Studies 3, no. 6: 292-304. DOI: $10.20474 /$ jabs-3.6.4

World Economic Forum. 2015. Index results: The travel \& tourism competitiveness index ranking 2015.

URL: https://bit.ly/1JA5A3C (accessed on March 21, 2016).

Yüksel, A. T. I. L. A., and F. I. S. U. N. Yüksel. The quest for quality and Competitiveness: A case of Turkish Tourism.

URL: https://bit.ly/2vmia7X (accessed on April 11, 2015).

Zengin, Murat, and Sevgi Yılmaz. 2010. Ardahan kura nehri ve yakın çevresi alan kullanımlarının belirlenmesi ve optimal alan kullanım önerileri. Atatürk Üniversitesi Ziraat Fakültesi Dergisi 39, no. 1: 43-54.

— This article does not have any appendix. - 